\title{
Vestígios de um crime imaginário em La noche de los asesinos, de José Triana
}

\author{
Sônia Aparecida dos Anjos \\ Doutoranda em Literatura Comparada / UFMG
}

\begin{abstract}
RESUMO
O presente ensaio é um breve estudo da peça La noche de los asesinos, do dramaturgo cubano José Triana. A temática da peça representa um crime imaginário: filhos que assassinam os próprios pais. Apresentaremos os principais elementos simbólicos presentes no texto e as evidencias de um crime imaginário, pois não temos certeza da veracidade ou não do parricídio.
\end{abstract}

\section{PALAVRAS-CHAVE}

Crime, revolução, loucura

O presente ensaio é um breve estudo da peça La noche de los asesinos, do dramaturgo cubano José Triana. Escrita entre os anos de 1958 e 1965, a obra ocupa um espaço significativo na história de Cuba e do período revolucionário. Agraciada com o Prêmio de Teatro de La Casa das Américas, a peça representa um marco na obra do autor, inserindo-a na perspectiva do teatro do absurdo e teatro da crueldade.

Composta por dois atos, La noche de los asesinos é uma obra complexa. O tema gira em torno de três irmãos e da pretensa tentativa deles em assassinar os pais. Logo, além de contemplar o processo revolucionário, suas origens e suas consequências, Triana evidencia que, em sua rebeldia, os jovens são tão brutais quanto os pais e uma vez no poder não se comportam de maneira diferente. Assim, a trama trata da revolução, questiona a sua natureza e o seu significado. Ora, se antes o autor estava entusiasmado com o processo revolucionário,

\footnotetext{
${ }^{1}$ As obras de José Triana anteriores a La noche de los asesinos são: El mayor general hablará de Teogonía (1957), Medea en el espejo (1960), El parque de la fraternidad (1962), La casa ardiendo (1962) e La muerte del ñeque (1963). As peças Medea en el espejo, La muerte del ñeque, La noche de los asesinos formam uma trilogia, respeitando a estrutura das tragédias gregas.
} 
rapidamente compreendeu a ilusão em que se envolveu. Desta forma, com a referida peça, o autor corrobora que a revolução não significou necessariamente: liberdade.

O jogo de iluminação denuncia uma premissa universal: a vivência do homem com as sombras e a luz. A noite configura-se como o reino do perigo, da inconstância, simboliza o tempo das conspirações, o espaço do horror e da crueldade. Por conseguinte, a noite é a grande imperatriz desse espetáculo, em que o próprio título da peça, La noche de los asesinos, encontra-se carregado de simbologia. Para Chevallier e Gheerbrant, "entrar na noite é regressar ao indeterminado, onde se misturam pesadelos e monstros”.

Nesse espaço inóspito e sombrio, Triana nos conduz para o mundo claustrofóbico de três monstros (talvez vítimas) em potencial: os irmãos Lalo, Beba e Cuca, personagens obcecadas em matar os pais. Infiltrados no sótão, eles se envolvem numa trama macabra e enigmática. Os irmãos se multiplicam em diversos outros personagens, além deles próprios. Se no primeiro ato eles encarnam seres específicos: Margarida, Pantaleão, a mãe, o pai; no segundo, eles se transformam em seres definidos por sua profissão: chefes de polícia, jornaleiro, promotor de justiça, juiz, secretária/escrivã, etc.

Mas, para além da sensação de desconcorto motivada pelo espaço diminuto, somos acometidos por constantes dúvidas, pois não somos capazes de afirmar a veracidade dos acontecimentos que giram em torno da ação dramática: o parricídio. Em alguns momentos somos levados a crer que o assassinato ainda não aconteceu. Mas também chegamos a acreditar que, consumados pela consciência, eles repetem o crime passo a passo como forma de autopunição.

Triana estimula nosso imaginário recomendando na primeira didáscalia um espaço cênico fechado, escuro e sombrio: o sótão ou o porão da casa. O ambiente é sórdido e a composição desse espaço indica desordem, sujeira e decadência, provocando nas personagens medo, agressividade e sufocamento, ao mesmo tempo que desperta a loucura e a alienação. A cena inicial nos remete à conspiração, ao perigo constante, à vigilância e à repressão. O autor define as personagens como figuras de um museu em ruínas. ${ }^{6} \mathrm{O}$ museu, espaço de memória,

\footnotetext{
${ }^{2}$ TAYLOR. Framing the Revolution: Triana's La noche de los asesinos and Cerimonial de guerra, p. 83 e 87.

${ }^{3}$ CHEVALIER; GHEERBRANT. Dicionário de símbolos, p. 474.

${ }^{4}$ CHEVALIER; GHEERBRANT. Dicionário de símbolos, p. 474. (texto adaptado)

MELÉNDEZ. El espacio dramático como signo: La noche de los asesinos, de José Triana, p. 31.

${ }^{6}$ TRIANA. La noche de los asesinos, p. 1.
} 
metaforicamente em destroços, dificulta a organização dos fatos. As personagens são personas em decadência, em processo de desmoronamento.

A cenografia fortalece da temática da peça com o enclausuramento das personagens encerradas em si mesmas e o desaparecimento gradual da realidade física que as circundam. $\mathrm{O}$ confinamento também é sentido pelo público que, simultaneamente fora e dentro do cenário, não pode interferir e nem sair dali. E na prisão virtual autoinstituída no sótão temos a confissão do assassinato. Os jovens reencenam infinitamente o parricídio nos remetendo ao ciclo de assassinatos tão comuns no contexto mítico. ${ }^{7}$ Teríamos na peça uma breve alusão ao mito de Cronos, Zeus, Édipo, Orestes e outros que atentaram contra a vida de seus genitores. ${ }^{8}$

LALO: Cierra esa puerta. (Golpeándose el pecho. Exaltado, com los ojos muy abiertos.) Un asesino. Un asesino. (Cae de rodillas.)

CUCA: (A Beba) ¿Yeso?

BEBA: (Indiferente. Observando a Lalo.) La representación há empezado.

CUCA: ¿Otra vez?

BEBA: Mira que tú eres... ¡Como se fuera algo nuevo! ${ }^{9}$

A primeira frase de Lalo é: “feche essa porta”. Entramos no espaço cênico através do corpo e da voz do ator. ${ }^{10}$ A porta, o limite máximo entre o exterior e o interior desse espaço, está cercada de simbolismo. Mas quem fecha e abre a porta continuará sendo o mesmo de antes ${ }^{11}$ Chevalier e Gheerbrant nos instruem no deciframento desse símbolo:

A porta simboliza o lugar de passagem entre dois estados, entre dois mundos, entre o conhecido e o desconhecido, a luz e as trevas, o tesouro e a penúria. Indica passagem e travessia. Como lugar de passagem, e particularmente de chegada, evoca também uma idéia de transcendência, acessível ou proibida, conforme está aberta ou fechada, transposta ou simplesmente vista. ${ }^{12}$

Ligada à noção de espaço fechado, a porta serviria simultaneamente como barreira e a única forma de transposição desse espaço para outro. Representaria o acesso à prisão física e psicológica dos irmãos permitindo-lhes que se isolem do mundo para tecerem seus planos

\footnotetext{
${ }^{7}$ TAYLOR. Framing the revolution: Triana's La noche de los asesinos and Cerimonial de guerra, p. 84.

${ }^{8}$ Essa aproximaçao será tema de outro ensaio.

${ }^{9}$ TRIANA. La noche de los asesinos, p. 3. Através da didascália sugerindo "olhos muito abertos", ritualizamos a máscara do teatro antigo através da desfiguração da face de Lalo.

${ }^{10}$ BARRANCO. Artaud y La noche de los asesinos, p. 47.

${ }^{11}$ BACHELARD. A poética do espaço, p. 226.

${ }^{12}$ CHEVALIER; GHEERBRANT. Dicionário de símbolos, p. 537-539. ( texto adaptado)
} 
malignos. O sótão também se define como símbolo; é como se tivesse corpo e alma; além disso, representa o enclausuramento duplo, pois é espaço inserido dentro da casa.

A sensação de confinamento é reinterada devido às condições físicas do espaço opressor. $^{13}$ Ou seja, com a porta trancada os encarcerados não poderiam sair espontaneamente, mas também ninguém poderia entrar. Porém, se a porta está apenas encostada no ferrolho a magia daquele instante poderia ser quebrada com a presença de algum intruso.

Segundo Jesús Barranco, o espaço proposto por Triana é a metáfora do útero e da Caverna de Platão. As personagens estariam condicionadas a visualizar sombras entrelaçadas à lembraças fragmentadas e a mergulhar num mundo opressor e violento. ${ }^{14}$ Assim este espaço se projeta na mente atormentada dos protagonistas. Em nenhum instante temos a indicação de uma saída possível para o drama vivido pelos irmãos. Numa trama alucinante e cíclica eles revivem situações que se manifestam no imaginário. Não obstante, Beba, em sua mimesis de Lalo, nos lembra que tudo é um “espetáculo”. Ou seja, é perfomance, teatro dentro do teatro, encenação. Vejamos como essa condição se manifesta no texto dramático:

LALO: Yo los maté. (Se ríe. Luego extiende los brazos hacia el público en ademán solemne.) ¿No estás viendo ahí dos ataúdes? Mira: los cirios, las flores (...) (Pausa.) Yo mismo he vestido esos cuerpos rígidos, viscosos. Y he cavado con estas manos un hueco bien profundo. Tierra, venga tierra. (Rápido. Se levanta.) ${ }^{15}$

Lalo indica para nós, leitores/espectadores, os corpos dentro dos caixões, as velas, as flores e os ornamentos fúnebres imaginários. Sua performance é enigmática, mas sugestiva. Tudo é alucinação, somos obrigados a visualizar o invisível e compactuar com o ilusionismo sugerido por Lalo. As velas e as flores também possuem significado simbólico, pois os círios que ardem próximos aos defuntos simbolizam a luz da alma na sua força ascensional e a própria perenidade da vida, assim como as flores simbolizam o arquétipo da alma.

Aparentemente a desordem e a sujeita (associadas ao crime) ocupam espaço substancial na trama. Cuca se preocupa em limpar o sótão, um ambiente asqueroso onde pululam baratas, ratos, traças e centopeias. Mas a sujeira do sótão, real ou imaginária, não

\footnotetext{
${ }^{13}$ MELÉNDEZ. El espacio dramático como signo: La noche de los asesinos, de José Triana, p. 27.

${ }^{14}$ BARRANCO. Artaud y La noche de los asesinos, p. 47.

${ }^{15}$ TRIANA. La noche de los asesinos, p. 3-4.

${ }^{16}$ CHEVALIER; GHEERBRANT. Dicionário de símbolos, p. 679.

${ }^{17}$ CHEVALIER; GHEERBRANT. Dicionário de símbolos, p. 330.
} 
pode ser facilmente extirpada. Na verdade, a própria vida só seria possível se, dentre outras coisas, os irmãos fossem capazes de vencer o medo. A atmosfera é opressiva, os irmãos viviam subjugados pela autoridade e violência paterna. Lalo se lembra dos castigos físicos e psicológicos constantemente recebidos, tornando o assassinato dos pais uma proposta perigosa, mas também a única saída para que eles pudessem escapar daquela condição em que se encontravam.

Com o assassinato eles deram um passo rumo à liberdade. Porém, entram em cena duas personagens imaginárias: Margarida e Pantaleão. O aparecimento destas personagens, intrusos na consciência dos irmãos, sugere o possível fracasso de um plano aparentemente brilhante: livrar-se dos pais opressores. O segredo, trancafiado entre as paredes do sótão, torna-se passível de ser desvendado. Eles passam a se comportar como se as personagens estivessem lá, incorporando-as em suas vozes e gestos. Apesar da cordialidade velada, os irmãos se sentem ameaçados e tentam se livrar da presença indesejável dos visitantes invisíveis.

Além disso, o espectro do pai incorpora em Beba e ritualiza a autoridade paterna. Lalo reconhece a sua insignificância e a de suas irmãs, meros objetos manuseados ao bel-prazer dos pais manipuladores. Portanto, ele anseia viver, pensar e agir livremente. Mas, com os olhos vendados, os pés e as mãos atados, sua vida se resume àquela casa velha, suja e malcheirosa. Tal recomendação do autor poderia nos remeter ainda ao inconsciente dos protagonistas, o “eu” mais sombrio de cada um deles.

No decorrer da trama o crime imaginário atinge repercussão. Na divulgação do crime a imprensa sensacionalista não poderia ser descartada. Cuca se transforma num vendedor de periódicos ressaltando o assombroso delito. A imprensa descreve o horror do crime. $\mathrm{O}$ excesso de sangue acentua o horror da cena descrita pelo jornaleiro.

CUCA: (Gritando.) Avance. Última noticia. El asesinato de la calle Apodaca. Cómprelo, señora. No se lo pierda, señorita. Un hijo de treinta años mata a sus padres. ¡Mira..., cómo corrió la sangre!... El suplemento con fotografías. (Casi cantando.) Les metió a los viejo cuarenta puñaladas. Cómprelo. Última noticia. Vea las fotos de los padres inocentes. No deje de leerlo, señora. Es espantoso, caballero. Avance. ${ }^{20}$

\footnotetext{
${ }^{18}$ TRIANA. La noche de los asesinos, p. 4-6.

${ }^{19}$ TRIANA. La noche de los asesinos, p. 21-25.

${ }^{20}$ TRIANA. La noche de los asesinos, p. 35.
} 
Noutra cena, Beba continua imitando o pai e destrata Lalo ameaçando prendê-lo num quarto escuro, prisão velha conhecida dos irmãos atormentados. Nesse intervalo, presos no quarto escuro, os irmãos poderiam entrar em contato com o próprio monstro interior. As trevas, a tormenta e o desequilíbrio mental nascem das sombras desse quarto, útero de um crime familiar. Daí, não suportando as péssimas condições de vida, eles se organizam para executarem o crime. Ao assassinarem os pais (imaginariamente ou não), os irmãos precisam se livrar dos vestígios do delito, agir normalmente e encerrar a primeira parte da trama.

LALO (...) (Pausa. Decidido.) Ahora hay que limpiar la sangre. Bañarlos. Vestirlos. Y llenar la casa de flores. Después, abrir un hueco muy hondo y esperar que mañana... (Pensativo.) ¡Qué sencillo y terrible!

Las hermanas han terminado de cantar. Cuca recoge el cuchillo y comienza a limpiarlo con el delantal. Pausa larga. (...)

LALO: Abre esa puerta (Se golpea el pecho. Exaltado. Con los ojos muy abiertos.) Un asesino. (Cae de rodillas.)

CUCA: (A Beba.) ¿'Y eso?

BEBA: La primera parte ha terminado. ${ }^{21}$

Lalo ordena que a porta seja aberta, enquanto Beba alerta-nos para o final da primeira parte do espetáculo. Para os irmãos o assassinato dos pais significaria o fim da tirania, porém a opressão encontra-se recalcada em suas mentes. Outro aspecto significativo é a descrição da quantidade de sangue em cena, obrigando-nos a ver o invisível. Após o assassinato, Cuca aparece limpando a faca suja de sangue. A faca encontra-se associada à ideia de execução judicial, de morte, de vingança, de sacrifício; ${ }^{22}$ além disso, nos remete ao princípio dos ritos afrocubanos, em que o sangue ocupa lugar de destaque. Cabe acrescentar que esse rito é um reajuste de contas entre sujeitos unidos por laços consanguíneos.

No segundo ato, Lalo retoma a frase "cierra esa puerta" ${ }^{23}$ Nessa fase temos a descoberta do parricídio, a voz dos mortos exigindo justiça, a investigação criminal, o julgamento e o recomeço incógnito. ${ }^{24}$ Após o crime eles aguardam a chegada da polícia. Temos uma apurada investigação em busca dos vestígios (invisíveis) de um assassinato.

As irmãs incorporam dois polícias que entram no sótão e caminham como se entrassem numa galeria escura, descrevendo o local como malcheioroso. É a indicação de que o espaço cênico é labiríntico. Elas/policiais identificam manchas de sangue por toda parte,

\footnotetext{
${ }^{21}$ TRIANA. La noche de los asesinos, p. 51-52.

${ }^{22}$ CHEVALIER; GHEERBRANT. Dicionário de símbolos, p. 314. (texto adaptado)

${ }^{23}$ TRIANA. La noche de los asesinos, p. 55.

${ }^{24}$ DAUSTER. The Game of Chance: the theatre of Jose Triana, p. 6.
} 
enquanto Lalo permanece inerte e sentado. Os policiais/irmãs encontram o suspeito e o interrogam.

BEBA: (Como otro policía.) Me parece que han matado a dos puercos, en lugar de cristianos. (...) A éste no hay quien lo salve, mi hermano. (Se ríe. Grosero.) Éste es un delincuente de marca mayor. Seguramente robó primero; y luego, no satisfecho, decidió matarlos. (A Lalo.) ¿A tus padres, no?... Casi me lo imagino. ¿Los envenenaste? (Toma en sus manos el tubo de pastillas y vuelve a colocarlo en la mesa.) ¿Cuántas pastillas...? (Lalo no responde. Sonríe de vez en cuando.) Vamos, escupe... Si hablas, puede que el castigo sea menor. (...)

CUCA: (Como un policía.) A todas luces éste es un crimen de los gordos. (A Lalo.) ¿Dónde están los cadáveres? ( $A$ Beba.) No hay rastro alguno.

BEBA: (Como un policía.) ¿Dónde los escondiste? ¿Los enterraste?

CUCA: (Como un policía.) Hay que registrar la casa de arriba abajo. En cualquier rincón...

BEBA: (Como un policía.) ¿Por qué los mataste? Responde. ¿Te maltrataban?

LALO: (Secamente.) No. (...)

CUCA: (Como un policía.) No me irás a decir que todo ha sido un juego. Aquí están las manchas de sangre. Tú mismo estás embarrado de pies a cabeza. ¿Serás capaz de negarlo? ¿Te niegas al interrogatorio? (En otro tono.) Yo casi he visto el crimen... (Rápido, casi insólito.) ¿Dónde están tus padres? ¿Encerrados en un baúl? (Pausa. Reconstruyendo la escena.) (...) Ah, esta casa es un laberinto. ${ }^{25}$

Notando a inquietação de Lalo, reconhecem nele um assassino. Sangue imaginário o cobre dos pés à cabeça e encontra-se espalhado pelo sótão. A motivação do crime permanece misteriosa. Ele é identificado como um assassino cruel, frio e violento. Os policiais sugerem a confissão como um passo para atenuarem seu castigo. Porém, como o autor parece sugerir, quem experimenta a violência muitas vezes prefere o silêncio, portanto, Lalo é monossilábico.

A entrada no sótão assemelha-se a um labirinto, e a menção ao labirinto possui um efeito espetacular importante para a cena porque a casa se apresenta como uma encruzilhada apontando várias opções de caminhos que podem ou não indicar a saída. O sótão labiríntico é o espaço que conduz as personagens para o interior de si mesmas, remetendo-as ao que o ser humano possui de mais misterioso:

CUCA: (...) (Reconstruyendo la escena.) Ahí están las palas y el azadón... Abrió un hueco enorme. No sé como pudo hacerlo solo... y allí, al fondo, los dos cuerpos y un poco de tierra encima. (Acercándose a Lalo. Dándole una palmada en el hombro.) (...) (Lo mira fijamente, con desprecio.) (...) (Tono vulgar.) Has firmado tu sentencia, mi hermano. (...)

BEBA: ¿Cómo...? Pero si no ha confesado.

CUCA: (Como un policía.) No es necesario.

\footnotetext{
${ }^{25}$ TRIANA. La noche de los asesinos, p. 62-68.

${ }^{26}$ CHEVALIER; GHEERBRANT. Dicionário de símbolos, p. 396.
} 
BEBA: Yo creo que sí.

CUCA: (Como un policía.) Hay pruebas suficientes.

BEBA: Debemos intentarlo... (Acercándose a Lalo.) Lalo, es necesario que digas, que hables, que hables. ¿Por qué, Lalo?

CUCA: (Como un policía.) No te ablandes.

BEBA: (A Lalo. Casi suplicante.) ¿No comprendes que es un requisito, que es importante la confesión? Di lo que quieras, lo que se te ocurra, aunque no sea lógico, aunque sea un disparate; di algo, por favor. (Lalo permanece impenetrable. $)^{27}$

A reconstituição da cena do crime chama a atenção para os corpos encontrados. A confissão, do ponto de vista de um dos policiais, torna-se desnecessária devido às provas criminais. Mas a narrativa vertiginosa de Lalo é absolutamente traumática e significa uma prestação de contas da personagem com o mundo e consigo mesmo. Na verdade, só sabemos do ato de Lalo por intermédio de suas palavras. Verdadeiro ou não, seu enunciado é o denunciador do delito. Na didáscalia, o autor orienta que a cena deverá adquirir uma dimensão estranha e a sonoplastia direciona nosso imaginário para outro espaço cênico: um tribunal.

CUCA: (En el tono anterior.) (...) dos cuerpos que presentaban (...) contusiones y profundas heridas de primer grado (...)

LALO: (Furioso, firme, desafiante.) No acepto. ¿Me entienden? Todo esto es una porquería. Todo esto es una infamia. (Pausa. En otro tono, casi burlón.) Me parece magnifico, admirable, que así de buenas a primeras, ustedes traten, empleando los medios más asquerosos, de hacerme un interrogatorio. (...) ¿Eso es la ley? ¿Eso es la justicia? ¿Qué saben ustedes de todo eso? (Gritando. Rompe el acta.) (...) (Patea y pisotea con rabia los papeles rotos. Pausa. En otro tono. Con una sonrisa amarga y casi con lágrimas en los ojos.) Es muy simpático, muy digno, muy ejemplar que ustedes ahora digan: culpable. (...)

BEBA: (Como un juez.) Ruego al público que mantenga la debida compostura y silencio, o de lo contrario, tendré que desalojar la sala y continuar las sesiones a puertas cerradas. (А Сuca.) Tiene la palabra señor fiscal. $^{28}$

Temos a descrição dos corpos das vítimas e as marcas deixadas pelos ferimentos. Lalo questiona os meios ilícitos utilizados para lhe extrair a confissão. Se essa a é lei, se isso é a justiça, é fácil julgá-lo culpado. Não lhe resta nenhum mecanismo de defesa capaz de salvá-lo de uma acusão inevitável, tampouco abrir-lhe espaço para apresentar as motivações do crime. Ora, a justiça deveria representar mais do que um mero conjunto de leis, o fruto de uma convenção ou acordo entre os homens; mas o marco a partir do qual os homens construíram

\footnotetext{
${ }^{27}$ TRIANA. La noche de los asesinos, p. 68-71.

${ }^{28}$ TRIANA. La noche de los asesinos, p. 72-76.
} 
as leis e o respeito às mesmas. Sem esta matriz, este sentido mítico do que é permitido e do que é interdito; a lei não teria força de convocar o seu cumprimento. A trama se desenrola como um fio que se desconstura de uma teia:

CUCA: (Como un fiscal. Solemne.) Le repito al señor juez que el procesado obstaculiza sistemáticamente todo intento de esclarecer la verdad. Por tal motivo, someto a la consideración de la sala las siguientes preguntas: ¿puede y debe burlarse a la justicia? ¿Si podemos burlarnos de la justicia, la justicia no deja de ser justicia?... ¿ Si debemos burlarnos de la justicia, es la justicia otra cosa y no la justicia? (...) (Como un fiscal. Solemne y furioso. A Beba.) La justicia no puede detenerse pasivamente ante un caso semejante, donde toda la abyección la malevolencia y la crueldad se reúnen. He aquí, señoras y señores, al más repugnante asesino de la historia. Vedlo. ¿No siente repulsión cualquier criatura frente a este detritus, frente a esta rata nauseabunda, frente a este escupitajo deleznable? ¿No siente la necesidad del vómito y del improperio? ¿Puede la justicia cruzarse de brazos? Señoras y señores, señores del jurado, señores de la sala, ¿podemos admitir que un sujeto de tal especie comparta nuestra ilusiones y nuestras esperanzas? $\dot{A}$ caso la humanidad, es decir, nuestra sociedad, no marcha hacia el progreso resplandeciente, hacia una alborada luminosa? (Lalo intenta balbucear algunas palabras, pero el torrente oratorio de Cuca impide cualquier acto, gesto o palabra.) Vedlo, indiferente, imperturbable, ajeno a cualquier sentimiento de ternura, comprensión o piedad. Ved ese rostro. (En un grito.) Un rostro impasible de asesino. El procesado niega haber cometido el asesinato por dinero, es decir, para robar, o para convertirse en el usufructuario de la pequeña pensión de sus padres. ¿Por qué mató, entonces? Porque, en realidad, no existe ningún móvil concluyente. ¿Tendremos entonces que convenir en que fue por odio? ¿Por venganza? ¿Por puro sadismo? (Pausa. Lalo se mueve impaciente en su silla. Cuca, en tono mesurado.) ¿Puede la justicia admitir que un hijo mate a sus padres?

LALO: (A Beba.) Señor juez..., yo quisiera, yo desearía...

CUCA: (Como un fiscal.) No, señores del jurado. No, señores de la sala. Mil veces no. La justicia no puede admitir tamaño desacato. La justicia exige las buenas costumbres. La justicia salvaguarda al hombre de los instintos primitivos y corruptores. ¿Podemos tener piedad de una criatura que viola los principios naturales de la justicia? Yo pregunto a los señores del jurado, yo pregunto a los señores de la sala: ¿existe a caso la piedad? (Pausa.) Pero nuestra ciudad se levanta, una ciudad de hombres silenciosos y arrogantes avanza decidida a reclamar a la justicia el cuerpo de este ser monstruoso... Y será expuesto a la furia de hombres verdaderos que quieren la paz y el sosiego. (En tono grandilocuente.) Por lo tanto exijo al procesado que contribuya a poner orden en el conocimiento de la realidad de los hechos. $(A$ Lalo.) ¿Por qué mató a sus padres?

LALO: Yo quería vivir. ${ }^{29}$

Verdades e tormentos ressoam no ar. Respingam-se recriminações sob o manto da justiça. O interrogatório é o confronto entre Cuca/promotor e Lalo/réu na tentativa do primeiro tornar o outro submisso, vencendo-o pela linguagem. Para Cuca/promotor, Lalo

${ }^{29}$ TRIANA. La noche de los asesinos, p. 77-82. 
utilizou uma série de embustes tornando impossível esclarecer os fatos. Ela volta-se à audiência e questiona o papel da justiça, considerando inadmissível sua passividade perante crimes abjetos. Lalo é o autor de um crime inominável, ela convida a todos (jurados, audiência e presentes) a verem nele a ruptura com a condição humana. Ela discorre contra ele uma série de impropérios, descrevendo-o como um sujeito cruel, nogento, vil e detestável. Caso ele seja inocentado, a humanidade poderia retornar a sua condição animal. Lalo, o parricida, seria um monstro em potencial.

Lalo é o executor, o mais violento, maltratado e ressentido dos irmãos. Porém, mesmo antes de confessar qualquer crime, ele já está sofrendo um castigo. E quando ele confessa é porque queria se livrar da pressão externa, cumprir com suas obrigações para com a justiça e para que os rigores da lei não recaiam sobre ele. Segundo Cuca/promotor, não seria prudente pedir e nem sentir clemência por um sujeito que atenta contra a própria família sem qualquer razão aparente ou justificável. Porém, Lalo se sentia perseguido, acusado, vigiado, ele não podia dormir, nem sonhar ou mesmo ler.

Mas Cuca/promotor dirige-se à plateia questionando a futilidade dos motivos apresentados por Lalo em sua defesa. Mas, Lalo não desiste de afirmar seu desejo desesperado pela vida. Sôfrego, ele ainda desabafou que era constantemente torturado por horas intermináveis num quarto escuro, ele era golpeado e castigavam duramente, dizia-lhe que ele deveria morrer, que não sobreviveria sem a ajuda deles, humilhando-o e ferindo-o fisicamente.

Nesse sentido, Lalo parece-nos desiquilibrado. Ele afirma que não há culpados ou vítimas; mas existem responsáveis, seres fragmentados, asfixiados pela sociedade que os desconhece e não os ensina a se comportar de outro modo. Além disso, o sofrimento físico e mental causado a Lalo por seus pais é também uma aberração.

O suplício de Lalo está marcado pela sua condição de inferioridade perante os pais autoritários. Os enunciados dos pais, repetidamente no “imperativo”, o precondicionaram à esquizofrenia. Deveria contiuar se comportando como um homem/objeto, tal qual uma cadeira, um cinzeiro, uma mesa. Em seu delírio ele nos revela as alucinações provocadas pelo seu sofrimento.

LALO: Sí, es cierto. Me acostumbré. (A medida que Lalo avance en el monólogo se irá transformando.) Parece terrible, sin embargo... Yo no deseba que así fuera; pero la idea me daba vueltas y más vueltas, llegaba y se

\footnotetext{
${ }^{30}$ TRIANA. La noche de los asesinos, p. 82-87.
} 
iba, y volvía otra vez. Al principio quise borrarla... ¿ ¿usted me comprende...? Y ella insistía: "Mata a tus padres". Creí que iba a enloquecer, le aseguro que sí. Corría y me metía en la cama. A veces me entraban unas calenturas... Sí, tuve fiebre. Pensé que me desinflaría como un globo, que reventaba, que era el diablo quien me hacía señas; y temblaba entre las sábanas... Si usted supiera... No dormía; noches y más noches en vela. Tenía escalofríos... Y era espantoso porque vi que la muerte se me acercaba, poco a poco, detrás de la cama, entre las cortinas y entre las ropas del armario y se convirtió en mi sombra y me susurraba entre las almohadas: “Asesino.”, y luego desapareció como por encanto; y me ponía delante del espejo y contemplaba a mi madre muerta en el fondo de un ataúd y a mi padre ahorcado que se reía y me gritaba; y por las noches sentía las manos de mi madre en las almohadas, arañándome. (Pausa.) Todas las mañanas sufría al despertarme; era como si me despertara de la muerte abrazado a dos cadáveres que me perseguían en sueños. (...) (Pausa breve.) ¿Qué otra cosa podía hacer? Si no era esto, debía destruirlo todo, todo; porque todos eran cómplices y conspiraban contra mí y sabían mis pensamientos. Si me sentaba en una silla, la silla no era la silla, sino el cadáver de mi padre. Si tomaba un vaso de agua, sentía que lo que tenía entre las manos era el cuello húmedo de mi madre muerta. Si jugaba con el florero, caía de repente un enorme cuchillo al suelo. Si limpiaba las alfombras, no podía nunca terminar, porque era un coágulo de sangre. (Pausa.) (...) Oí un día una voz, no sé de dónde. Si esto me estaba ocurriendo, era algo grave, extraño, desconocido para mí y debía hablarlo, porque quizás inesperadamente, ocurriría una catástrofe y no era cuestión de confiar en mis fuerzas, pero no... Nadie comprendería. Se reirían, se burlarían. Oía entonces las carcajadas y los chistes de mis hermanas por los cuartos y en los corredores y en los patios de la casa... Y así, junto a las carcajadas y chistes de mis hermanas, sentí que miles de voces repetían al unísono: "Mátalos", "Mátalos”. No, no crea que es un cuento de camino. Se lo juro, es la verdad. Sí, la vedad... (Como un iluminado.) Desde entonces conocí cuál era mi camino y fui descubriendo que todo, las alfombras, la cama, los armarios, el espejo, los floreros, los vasos, las cucharas y mi sombra, en un murmullo, reclamaban: "Mata a tus padres." (Lo dice casi en éxtasis musical.) "Mata a tus padres.” La casa entera, todo, me exigía ese acto heroico. (Pausa.) $)^{31}$

A indicação imagética é admirável e provoca calafrios. A narrativa desperta o horror. Lalo sofria durante a noite quando era assaltado por vozes homicidas. A ideia obssessiva de matar os pais povoava o seu pensamento, indo e vindo vezes sem conta, persistente. Ele estava prestes a enlouquecer. Sua fala se caracteriza pela descrição de ilusões claramente formuladas, cuja maior parte é de caráter persecutório. As ilusões descritas são dispersas, mas inter-relacionadas. O sentimento de perseguição resulta de seu status de desconsideração por parte dos pais. Ele se torna prisioneiro de grande agitação e suas palavras soam em frenesi.

Ele se consome e se agita enquanto as suas palavras ressoam em “miragens” e “ilusões” que

\footnotetext{
${ }^{31}$ TRIANA. La noche de los asesinos, p. 90-94.

${ }^{32}$ FOUCAULT. História da loucura, p. 202.
} 
se agigantam perante nós. Se ele é um filho monstruoso, seus pais o geraram assim desde o útero por terem também seu quinhão de monstruosidade.

Compartilhamos de seus medos e visualizamos suas alucinações. Os delírios e as alterações de comportamento acentuam a psicose de Lalo. Ele tentava inutilmente se esconder da voz que lhe ordenava o assassinato de seus pais. A insônia tornara-se sua companheira. A própria personficação da morte apresenta-se como cena fantasiosa e fantástica a partir da descrição de Lalo. A morte se aproximava dele aos poucos e habitava seu quarto, tornara-se sua sombra e sussurrava em seu ouvido: assassino. Próprio da alucinação, a sombra da morte desaparecia como por encanto. Perseguido pelos fantasmas dos pais, ele podia vê-los através do espelho. Ora, nos rituais afrocubanos o espelho simboliza uma espécie de oráculo capaz de predizer o futuro ou indicar a ausência de alguém. Além disso, o próprio espelho, reprodutor de uma imagem invertida, refletiria mais do que uma simples imagem externa, mas o que havia de mais íntimo e obscuro na personagem: sua própria alma e seus mais terrificantes fantasmas. Todas as manhãs ele acordava abraçado aos cadáveres dos pais. Ensandecido, ele encontrava-se incapaz de distinguir o real do imaginário. Nós somos enlevados pelo frenesi da personagem e naufragamos em sua narrativa sem condições de definir a veracidade da mesma.

Cuca também incorpora o espírito da mãe e dirige-se ao público. Essa cena pode aludir aos que estão no tribunal, porém é também uma menção à representação: o teatro dentro do teatro. Ela questiona se seria possível Lalo comover o público com todo aquele embuste.

CUCA: (Como la madre. A Beba.) (...) Exijo una revisión de todo el proceso. Por eso he venido aquí. Yo deseo declarar. Mi hijo se presenta como una víctima y es todo lo contrario. Reclamo que se haga justicia en nuestro caso. (Beba comienza a repetir el tac-tac de la máquina de escribir. Exagerando.) Si usted supiera la vida que nos ha hecho pasar esta criatura. Es algo tan terrible. (...) (Como la madre.) No me jures nada. Te quieres pasar por bobo, pero conozco tus artimañas, tus rejuegos, tus porquerías. Por algo te parí. Nueve meses de mareos, vómitos, sobresaltos. Ése fue el anuncio de tu llegada. ¿Crees que has conmovido al público y que podrás salvarte? Dime, ¿de qué? (Se ríe con gran desparpajo.) ¿En qué mundo vives, mi hijito? (Burlándose.) Oh, ángel mío, me das pena. Verdaderamente eres, bueno, ¿para qué decirlo...? (...) Me gustaría que refrescaras la memoria. (Transformándose.) Señor juez, si usted supiera las lágrimas que he derramado, las humillaciones que he recibido, las horas de angustia, los sacrificios... Mire usted mis manos... Da lástima verlas. (Casi con lágrimas en los ojos.) Mis manos... Si usted las hubiera visto antes de casarme... Y todo lo he perdido por esta fiera. (A Lalo.) ¿No te avergüenzas? ¿Sigues creyendo que has realizado un acto heroico? (Con asco.) Miserable. No sé 
cómo pude tenerte tanto tiempo en mis enţ̧añas. No sé cómo no te ahogué cuando naciste. (Beba agita la campanilla.)

Nessas duas cenas teríamos a ressonância à Orésteia, de Ésquilo. O comportamento perturbado de Lalo aproxima-se da loucura que acomete Orestes no final das Coéforas e o enunciado de Cuca ao desabafo de Clitemnestra em Eumênides. ${ }^{34}$ Inconformada com os rumos do processo, o espírito da mãe de Lalo aparece para prestar seu testemunho. Ela tem sede de justiça e exige uma punição exemplar para o matricídio. Ela atribui ao filho a responsabilidade pela vida maldita que ela levava. Teria sido preferível tê-lo assassinado na infância, evitando dissabores. Deste modo, Triana questiona esse espaço rodeado de “paredes” onde se enclausuram sentimentos indescritíveis como o ódio, o medo e a revolta.

Através do fantasma do pai, Lalo salienta a incapacidade de escapar daquele mundo opressivo, pois ele deixara de viver seus desejos por puro medo. ${ }^{35}$ Além disso, o fim da trama não significa o fim da repressão; pois o enredo não indica uma saída. Assim, apesar dos irmãos buscarem o controle da situação, repetindo infinitas vezes o assassinato dos pais, a porta sempre estará pronta para abrir-se ou cerrar-se outra vez. Presos num pesadelo, eles repetirão o ritual infinitamente.

BEBA: Ayyyy (Entre sollozos.) Veo a mi madre muerta. Veo a mi padre degollado. (En un grito.) ¡Hay que tumbar esta casa! (Pausa larga.)

LALO: Abre esa puerta. (Cae de rodillas.)

Cuca lentamente se levanta, va hacia la puerta del fondo y la abre. Pausa. Se dirige hacia la mesa y toma el cuchillo $(. . .)^{36}$

Os irmãos da Rua Apodaca, cada um a sua maneira, pareciam possuídos pelo absurdo da situação. Ao final da peça eles se deparam com a indicação: abre essa porta. Eles saem de cena, mas voltam para o espaço opressor da casa. Terminamos a peça e ainda não somos capazes de afirmar se o crime aconteceu ou não. A cena repercute no imaginário dos irmãos obrigando-os a vivê-la incensantemente, como seres presos num labirinto de horrores. O assassinato simbólico (ou real) é mais que um parricídio; é um suicídio. É a própria mão que sai da tumba e os encerra naquele sótão escuro, é a mão que se automutila, é o gesto fatídico e mortal que os faz expirar o sopro da vida e mergulhar na morte.

\footnotetext{
${ }^{33}$ TRIANA. La noche de los asesinos, p. 94-97.

${ }^{34}$ Porém, será nosso assunto para outro artigo.

${ }^{35}$ TRIANA. La noche de los asesinos, p. 103-107.

${ }^{36}$ TRIANA. La noche de los asesinos, p. 109-110.
} 


\title{
CONSIDERAÇÕES FINAIS: FECHANDO O CICLO
}

Em La noche de los asesinos, José Triana critica a repressão como forma de educação e a violência como forma de convivência. Ele propõe um regresso à essência cubana, mergulhando no seu sentido mais profundo. Além disso, é inegável a presença dos rituais espíritas afrocubanos no enredo.

José Triana reflete o que o ser humano experimenta através da instabilidade da vida, sejam ou não chamados de revolução. Ela fala pela voz das personagens e nos faz escutar nossa própria voz. Naquela casa, naquele sótão, e naquelas mentes se encontram zonas obscuras que não nos atrevemos a explorar. Portanto, dois elementos foram fundamentais nessa análise: o espaço (sótão) e o tempo (noite).

Nesse sentido, a casa configura-se como um lugar de onde se deseja escapar, que aprisiona e impõe a ordem. A peça se desenvolve no sótão, metáfora do espaço mental das personagens. A revolta dos filhos contra os pais confunde o espaço cênico ao político, o momento histórico ao espetacular, a realidade ao imaginário porque os dois se tornam elementos indissociáveis. A peça atua sobre o subconsciente da plateia, ${ }^{37}$ expondo a violência como condição inevitável da sociedade. ${ }^{38}$

E para além do espaço sombrio imposto pelo sótão, a noite é cor dos desejos reprimidos e a parte obscura da consciência dos irmãos. Em termos cênicos, o assassinato que nunca presenciamos de fato, pois o que temos é uma simulação, ocorreu provavelmente à noite, enquanto os pais dormiam. É um assassinato cuja encenação se oculta à maneira grega. Nunca saberemos se o crime ocorreu ou não, obrigando os irmãos a reencená-lo infinitamente como seres presos numa roda do tempo. Eles abrem e fecham a porta, fecha-se o ciclo: restalhes apenas exorcizar esses fantasmas e dar sentido às próprias vidas.

\begin{abstract}
This essay is a brief study of the play La noche de los asesinos, by Cuban playwright José Triana. The theme of the piece represents an imaginary crime: children who kill their own parents. I will attempt to show, through
\end{abstract}

\footnotetext{
${ }^{37}$ ALVAREZ-BORLAND; GEORGE. La noche de los asesinos: text, staging and audience, p. 40.

${ }^{38}$ ALVAREZ-BORLAND; GEORGE. La noche de los asesinos: text, staging and audience, p. 38.
} 
the symbolic elements in the text, the evidence of an imaginary crime as the veracity or not of the parricide is not clear.

\section{KEYWORDS}

Crime, revolution, insanity

\section{REFERÊNCIAS}

ALVAREZ-BORLAND, Isabel; GEORGE, David. La noche de los asesinos: text, staging and audience. Latin American Theatre Review, v. 20, n. 1, p. 36-48, Fall 1986.

BACHELARD, Gastón. A poética do espaço. Trad. Antônio de Pádua Danesi. São Paulo: Martins Fontes, 2000.

BARRANCO, Jesús. Artaud y La noche de los asesinos. Encuentro 4/5, p. 46-52, 1997.

CHEVAliER, J, GHEERBRANT, A. Dicionário de símbolos. Trad. Cristina Rodrigues e Artur Guerra. Lisboa: Teorema, 1994.

DAUSTER, Frank. The game of chance: the theatre of Jose Triana. Latin American Theatre Review, v. 3 n. 1, p. 3-8, Fall 1969.

MELÉNDEZ, Priscilla. El espacio dramático como signo: La noche de los asesinos, de José Triana. Latin American Theatre Review, v. 17, n. 1, p. 25-36, Fall 1983.

NIGRO Kirsten F. La noche de los asesinos: playscript and stage enactment. Latin American Theatre Review, p. 45-57, Fall 1977.

PARADÍ, Aristides Falcon. Antonin Artaud y el teatro de la crueldad en Cuba. Latin American Theatre Review, v. 37. n. 1, p. 95-104, Fall 2003.

TAYLOR, Diana. Framing the revolution: Triana's La noche de los asesinos and Cerimonial de guerra. Latin American Theatre Review, v. 24. n. 1, p. 81-92, Fall 1990.

TRIANA, José. La noche de los asesinos. La Habana: Casa de las Américas Cuba, 1965.

ZALACAÍN, Daniel. El asesinato simbólico en cuatro piezas dramáticas hispanoamericanas. Latin American Theatre Review, v. 19, n. 1, p. 19-26, Fall 1985. 